\title{
Erratum to: C-PHIS: A Concept Map-Based Knowledge Base Framework to Develop Personal Health Information Systems
}

\author{
Pramukh R. Karla • Varadraj P. Gurupur
}

Published online: 11 January 2014

(C) Springer Science+Business Media New York 2013

Erratum to: J Med Syst (2013) 37:9970

DOI 10.1007/s10916-013-9970-3

The original version of this article unfortunately contained a mistake. Varadraj P. Gurupur's affiliation should be Louisiana Tech University.

The online version of the original article can be found at http://dx.doi/org/ 10.1007/s10916-013-9970-3.

P. R. Karla

Department of Computer Science and Information Systems, Texas

A\&M University, Commerce, TX, USA

\section{P. Gurupur $(\bowtie)$}

Department of Health Informatics and Information Management, Louisiana Tech University, Ruston, LA, USA

e-mail: varadrajprabhu@gmail.com 